\title{
APPLICATION OF MULTI-ARRAY ELECTRICAL RESISTIVITY TOMOGRAPHY IN PT. BUKIT BAIDURI ENERGI COAL MINING-EAST KALIMANTAN
}

\author{
PENERAPAN MULTIKONFIGURASI TOMOGRAFI TAHANAN \\ JENIS PADA TAMBANG BATUBARA PT. BUKIT BAIDURI \\ ENERGI-KALIMANTAN TIMUR
}

\author{
PITER LEPONG ${ }^{1}$, SUPRIYANTO ${ }^{1}$, SRI WAHYUNINGSIH ${ }^{2}$, and HARDIYANTO ${ }^{3}$ \\ ${ }^{1}$ Geophysical Laboratory of Mulawarman University \\ ${ }^{2}$ Statistical Department of Mulawarman University \\ Samarinda, East Kalimantan, Indonesia \\ e-mail: pit.lepong@gmail.com \\ ${ }^{3} \mathrm{PT}$. Bukit Baiduri Energi \\ Bukit Harapan-Tenggarong Kutai Kartanegara, East Kalimantan
}

\begin{abstract}
Multi-array Electrical Resistivity Tomography survey was conducted in coal mining concession of PT. Bukit Baiduri Energi at the Marandai pit, Loa Janan District, Kutai Kartanegara-East Kalimantan. Data acquisition has been done using the MAE-X612 unit with 48 electrodes and 5 meters interval and the maximum length of the survey was 235 meters. The aim of the survey is to analyze resistivity images from three different electrodes configurations for interpreting coal seams and other lithologies. We deployed three configurations, including Wenner-Schlumberger, Dipole-Dipole, and Pole-Dipole in one traverse. The resistivity images analyses were constrained using geological and geophysical logging. The result shows that the Wenner-Schlumberger array is the reliable result comparing to the dipole-dipole and pole-dipole arrays. This technique will apply for further assessment to provide the reliable result in this coal mining concession. Electrical Resistivity Tomography offers rapid mapping for shallow mine working up to 45-meter depth. This method can be applied to one or two hour's measurements with 48 electrodes with maximum 5-meter electrodes interval. This method offers the possible saving of drilling cost by using resistivity profile for coal seam correlation instead of conducting more drilling.
\end{abstract}

Keywords: electrical resistivity tomography, multi-array, coal seam, lithology

\begin{abstract}
ABSTRAK
Pengukuran Electrical Resistivity Tomography menggunakan tiga konfigurasi telah dilakukan di lokasi pit Marandai PT. Bukit Baiduri Energi Kecamatan Loa Janan, Kabupaten Kutai Kartanegara-Kalimantan Timur. Pengambilan data dilaksanakan dengan menggunakan peralatan MAE-X612 dengan 48 elektroda dengan jarak elektroda maksimum 5 meter, sehingga panjang lintasan maksimum adalah 235 meter. Tujuan penelitian ini adalah untuk mengkaji konfigurasi yang optimal dalam eksplorasi batubara di area konsesi tambang batubara.Tiga konfigurasi yakni Wenner-Schlumberger, Dipole-Dipole dan Pole-Dipole telah diukur dalam satu lintasan. Penampang resistivitas yang diperoleh selanjutnya diinterpretasi dengan menggunakan kontrol data bor geologi dan geofisika logging. Hasil yang paling mendekati adalah metode Wenner-Schlumberger, sehingga direkomendasikan untuk digunakan dalam kegiatan eksplorasi dan produksi batubara khusus untuk daerah penelitian. Metode ini memberikan pilihan untuk diterapkan pada lokasi tambang atau eksplorasi pengeboran dangkal hingga kedalaman 45 meter di bawah permukaan. Pengukuran dapat dilakukan dalam rentang satu sampai dua jam untuk satu lintasan dengan 48 elektroda dengan spasi maksimum lima meter. Selain itu, metode ini juga diprediksi dapat mengurangi biaya pengeboran dengan menggunakan hasil penampang resistivitas untuk tujuan korelasi data pengeboran.
\end{abstract}

Kata kunci: tomografi tahanan jenis, multikonfigurasi, lapisan batubara, litologi 


\section{INTRODUCTION}

Indonesia has 128 billion tonnes of total coal resources and total reserves are estimated at 28.5 billion tonnes. The coal reserves-toproduction ratio is estimated at around 62 years at current production levels. However, fast extraction has questioned the viability of coal reserves to support a growing domestic market and large exports. By region, East Kalimantan hosts approximately one-third of the national total coal resources and reserves (Ministry of Energy and Mineral Resources, 2017). Capital expenditure of publicly listed coal mining company has been down significantly by $80 \%$ since 2012 as a result of significant lower of coal price (Indonesia Coal Mining Association, 2016). Exploration spending by coal companies drops sharply during the downturn as many cuts back on spending. The low investment made will result in no new reserves identified over next several years. Modern mineral exploration has driven largely by technology but coal exploration still relies mainly on drilling exploration. New technology has to accommodate and disseminate in the coal industry. New geophysical instruments and processing technologies help provide new insights into geology imaging and improved rapid mapping of the subsurface. As one of a frontier of geophysical exploration techniques, resistivity tomographic imaging technology has a wide application prospect.

\section{Kutai Basin Coal Formation}

The Tertiary Kutai Basin in East Kalimantan is one of the largest and deepest basins in Indonesia. The basin area about $60.000 \mathrm{~km}^{2}$ with depth up to $14 \mathrm{~km}$ below the present day of the Mahakam Delta (Hutchison, 1989). The basin is one of the most economical basins in Indonesia that produces hydrocarbon and coal since more than a century ago. The basin was formed in the middle Eocene as a result of extension linked to the opening of the Makassar Straits and the Philippine Sea (Cloke, Moss and Craig, 1999). Several articles differentiate the basin into two different sub-basins that is the upper and lower Kutai Basin (Moss et al., 1998; McClay et al., 2000). The western margin is characterized by the shallow basement and the uplifted metasedimentary rocks of the Central Kalimantan Belt. The lower Kutai basin is characterized by the Samarinda Anticlinorium, Mahakam Fold and thrust belt, and the Mahakam Delta. The division broadly corresponds with the position of gravity high in the Kutai Lakes region of the basin. The eastern margin is the shoreline and shelf margin which is parallel to a series of NNE-SSW Samarinda Anticlinorium Folds belt. Basin margin at the present-day is defined by basement highs of the Mangkalihat Ridge to the Nothern and the Pater Noster platform and Barito Basin to the south (Moss and Chambers, 2000).

Kutai basin is the second largest coal resources and reserves in Indonesia. Coalforming environment was initiated during a period of widespread Paleogene extension, which may have begun in the middle Eocene. Coal rank in the basin is low to moderate, ranging from lignite to highvolatile bituminous. The coals have low ash, high moisture and generally low sulfur (Land and Jones, 1987). Figure 1 showing the regional geology of coal-bearing formation comprises Early Miocene to Pliocene sediments of the Pamaluan, Pulau Balang, Balikpapan and Kampung Baru Formations (Daulay, Santoso and Ningrum, 2015), prograding eastwards of the deltaic deposition.

Most of the sediments dip variably, depending on the position within the structures, of between $10-70^{\circ}$. Coal seams are known in all three formations, the Pamaluan Formation coal seams ranging up to 1.5 meters in thickness and have a very high calorific value $(>6,800 \mathrm{kcal} / \mathrm{kg})$ ranging to coking coal in part. The Pulaubalang Formation coal is considered to have a good quality with a calorific value of between 6,000-6,500 kcal $/ \mathrm{kg}$ whilst the Balikpapan Formation coal is generally subbituminous with a calorific value of approximately 5,300$5,600 \mathrm{kcal} / \mathrm{kg}$.

\section{Electrical Resistivity Tomography}

The resistivity technique is a useful method for characterizing the subsurface materials in terms of their electrical properties. Variations in electrical resistivity (or conductivity) typically correlate with variations in lithology, water saturation, fluid conductivity, porosity and permeability, which may be used to map stratigraphic units, geological structure, sinkholes, fractures, and groundwater. 


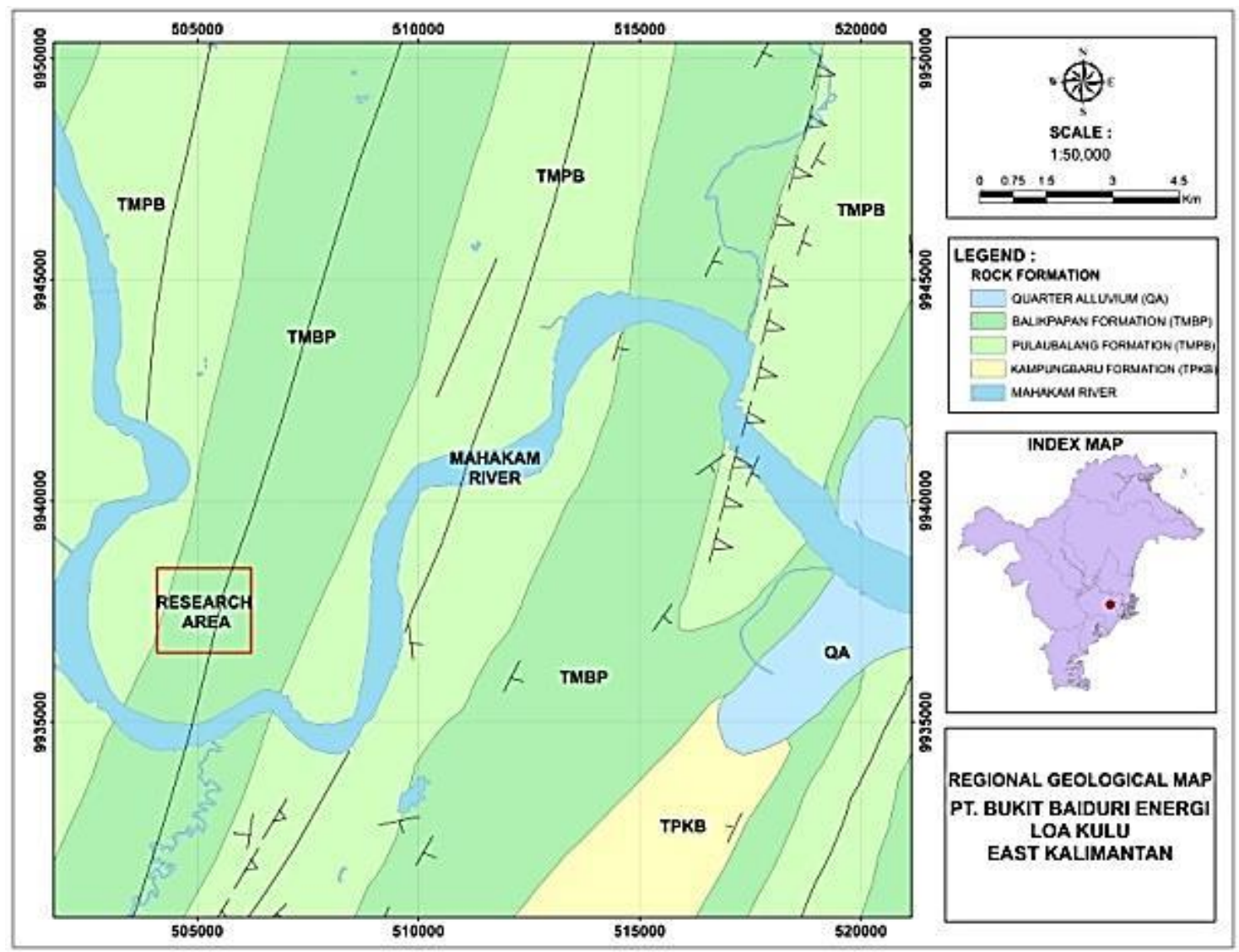

Figure 1. Regional Geology showing the coal-bearing formation of the Kutai Basin

The acquisition of resistivity data involves the injection of current into the ground via a pair of electrodes and then the resulting potential field is measured by a corresponding pair of potential electrodes. The field set-up requires the deployment of an array of regularly spaced electrodes, which are connected to a central control unit via multicore cables (Grigorova et al., 2017). Resistivity data are then recorded via complex combinations of current and potential electrode pairs to build up a pseudo cross-section of apparent resistivity beneath the survey line. The depth of investigation depends on the electrode separation and geometry, with greater electrode separations yielding bulk resistivity measurements from greater depths.

The recorded data are transferred to a PC for processing. In order to derive a crosssectional model of true ground resistivity, the measured data are subject to inversion process via RES2DINV software.

Data processing is based on an iterative routine involving a determination of a two- dimensional (2D) simulated model of the subsurface, which is then compared to the observed data and revised. Convergence between theoretical and observed data is achieved by non-linear least squares optimization. The extent to which the observed and calculated theoretical models agree is an indication of the validity of the true resistivity model (indicated by the final root-mean-squared (RMS) error).

The true resistivity models are presented as colour contour sections revealing spatial variation in subsurface resistivity. The $2 \mathrm{D}$ method of presenting resistivity data is limited where highly irregular or complex geological features are present and a 3D survey may be required. Geological materials have characteristic resistivity values that enable identification of boundaries between distinct lithology on resistivity cross-sections. At some sites, however, there are overlaps between the ranges of possible resistivity values for the targeted materials, which therefore necessitates the use of other 
geophysical surveys and/or drilling to confirm the nature of identified features.

\section{METHODOLOGY}

2-D electrical resistivity tomography (ERT) is carried out with a multi-electrodes resistivity meter system using MAE-X612 with 48 electrodes. A computer-controlled system is then used to automatically select the active electrodes for each measure (Griffiths and Barker, 1993).

In this study, field resistivity data were obtained along one traverse, oriented N-S direction along $235 \mathrm{~m}$ with 5-meter electrode spacing. According to Loke (2004), the characteristics of an array that should be considered in choosing array for field survey are (i) the sensitivity of the array to vertical and horizontal changes in the subsurface resistivity, (ii) the depth of investigation, (iii) the horizontal data coverage and (iv) the signal strength.

Three configuration array was applied, including Wenner-Schlumberger (WS), dipole-dipole (DD), and pole-dipole (PD). The choice of the optimum array for a field survey depends on the type of structure to be mapped, the sensitivity of the resistivity meter and the background noise level. The raw data were processed and displayed using the RES2DINV software. The data were filtered to remove bad datum points and inverted to estimate the true resistivity of the subsurface. Model refinement option of the "Inversion" menu was used to take care of the large resistivity variations near the ground surface. ERT inversion results are constrained with data from borehole such as lithology and a geophysical log of gamma-ray and long density.

\section{RESULTS AND DISCUSSION}

ERT result and interpretation show the inversion model and the geological interpretation derived from the ERT analysis. The high RMS error $(>10)$ indicates that the model is less accurate; therefore, anon reliable interpretation may be drawn from the ERT profile.The electric tomography, with a model maximum penetration depth of $45 \mathrm{~m}$, displays a variation of resistivity values both vertically and horizontally indicating that subsurface rocks are strongly differentiated by their electric properties, according to their lithologies and fracturing degree.

Three resistivity profiles have been inverted from one line traverse that distinguished ERT images of the different array. Survey traverse runs $235 \mathrm{~m}$ from south to north, parallel to strike line of the sedimentary structure. The survey area is almost flat, and therefore no considered topographic correction in any inverted profiles. The followings are the inverted profiles from three observed data with different configurations.

Profile-1: Wenner-Schlumberger (WS)

The resistivity profile of the WennerSchlumberger array is shown in Figure 2. Mudstone is the dominant features in this profile that is characterized by low resistivity value $<10 \Omega \mathrm{m}$. Two thin coal seams at the depth of $24 \mathrm{~m}$ and $30 \mathrm{~m}$ can be correlated with the resistivity value of $24 \Omega \mathrm{m}$ and 34 $\Omega \mathrm{m}$, respectively. The resistivity image of WS section shows clearly the sedimentary strata and stratigraphic features that conform to borehole data. Dip angle of the strata in this area around $10^{\circ}$ with EW dip direction. WS profile shows penetration up to $45 \mathrm{~m}$ depth compare to the $35 \mathrm{~m}$ depth of Dipole-Dipole.

\section{Profile-2: Dipole-Dipole (DD)}

The resistivity images of DD in Figure 3 shows that from surface up to $5 \mathrm{~m}$ depth, the resistivity varies between $10 \Omega m$ to $22 \Omega m$ which is interpreted to be associated with weathered soil. The middle layer that corresponds to the mudstone at the depth of $5-15 \mathrm{~m}$ is characterized by resistivity values of less than $10 \Omega \mathrm{m}$. The presence of the two coal seams at $24 \mathrm{~m}$ and $30 \mathrm{~m}$ depth are characterized by resistivities values of 24 $\Omega m$ and $34 \Omega m$ respectively.

Profile-3: Pole-Dipole (PD)

The depth profile of the PD array is $18 \mathrm{~m}$ as shown in Figure 4. The profile is very shallow, being compared to the WS and DD images. The profiles also show roughly boundaries between sedimentary layers. The features of high resistivity value at the near-surface correspond to the weathered soil. Table 1 shows the summary of resistivities values of the different array related to the coal seams and other lithologies of borehole logging. 
Application of Multi Array Electrical Resistivity Tomography in PT. Bukit Baiduri ... Supriyanto et al.

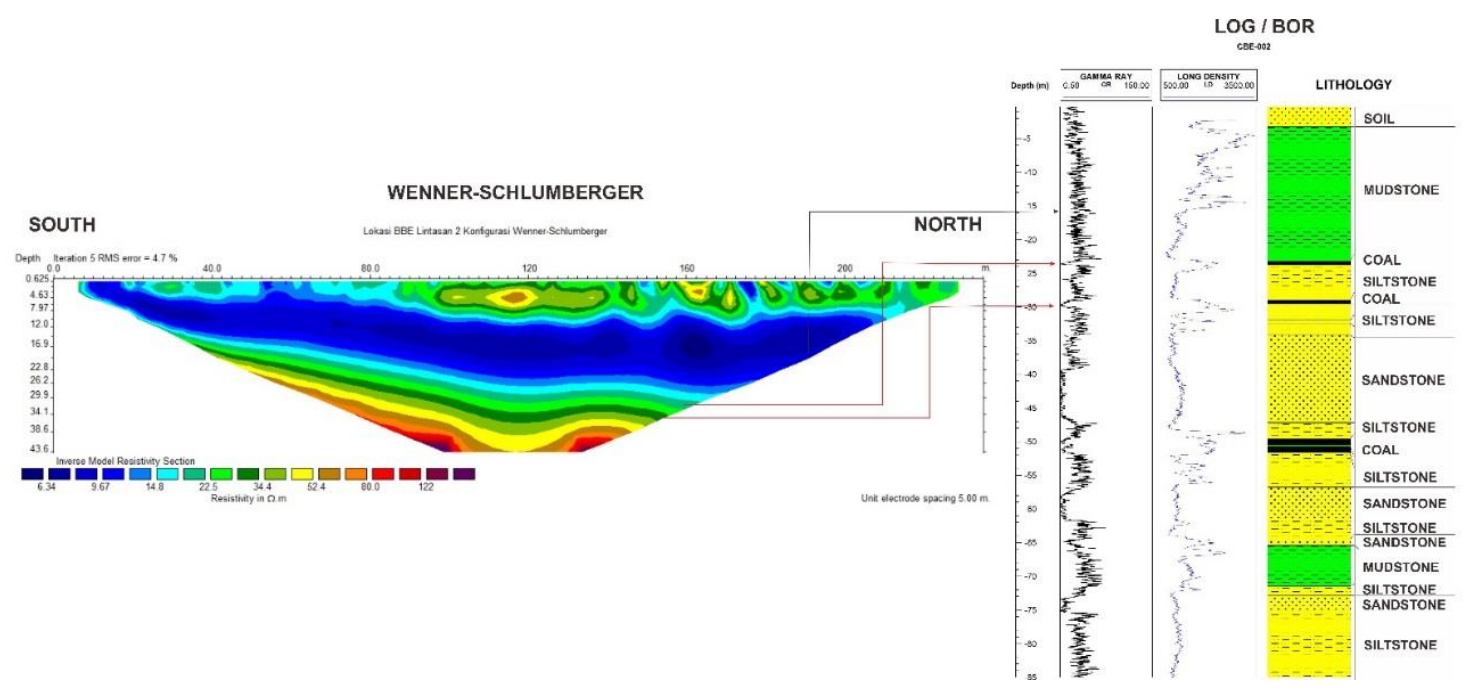

Figure 2. Resistivity profile of Wenner-Schlumberger array

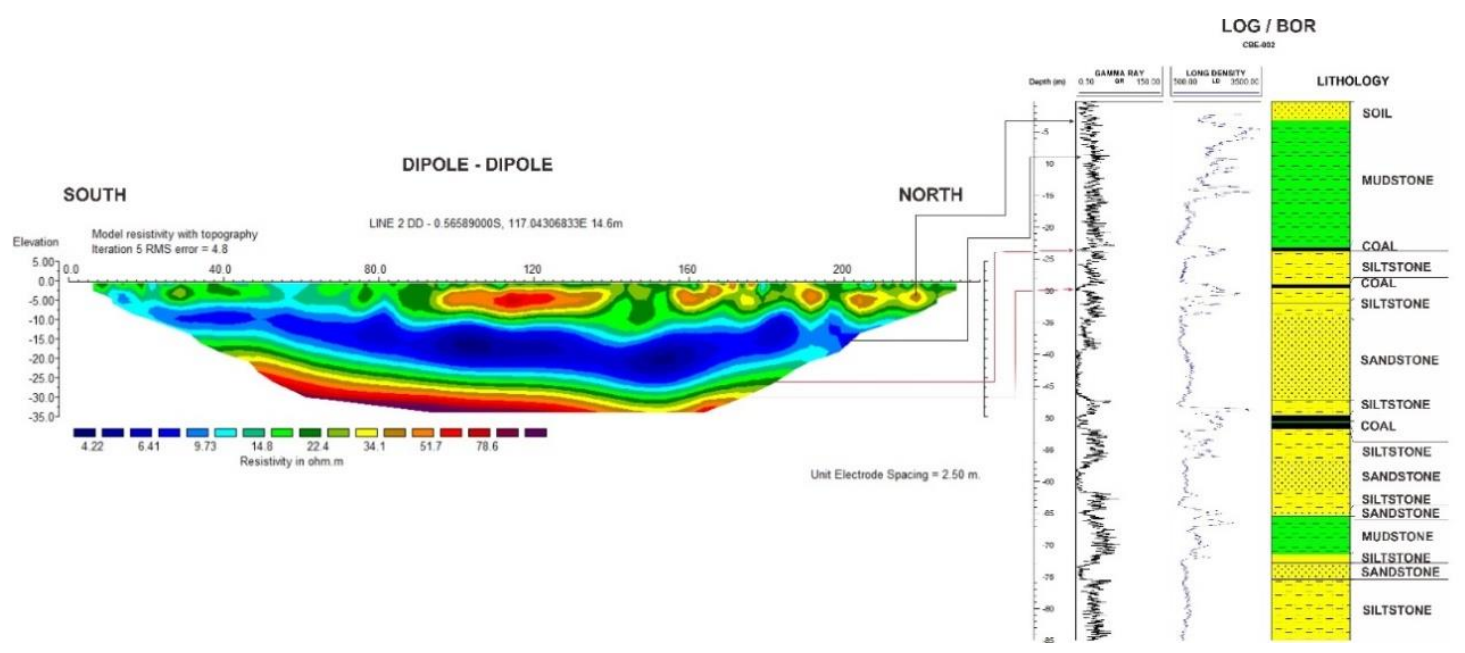

Figure 3. Resistivity profile of Dipole-Dipole array

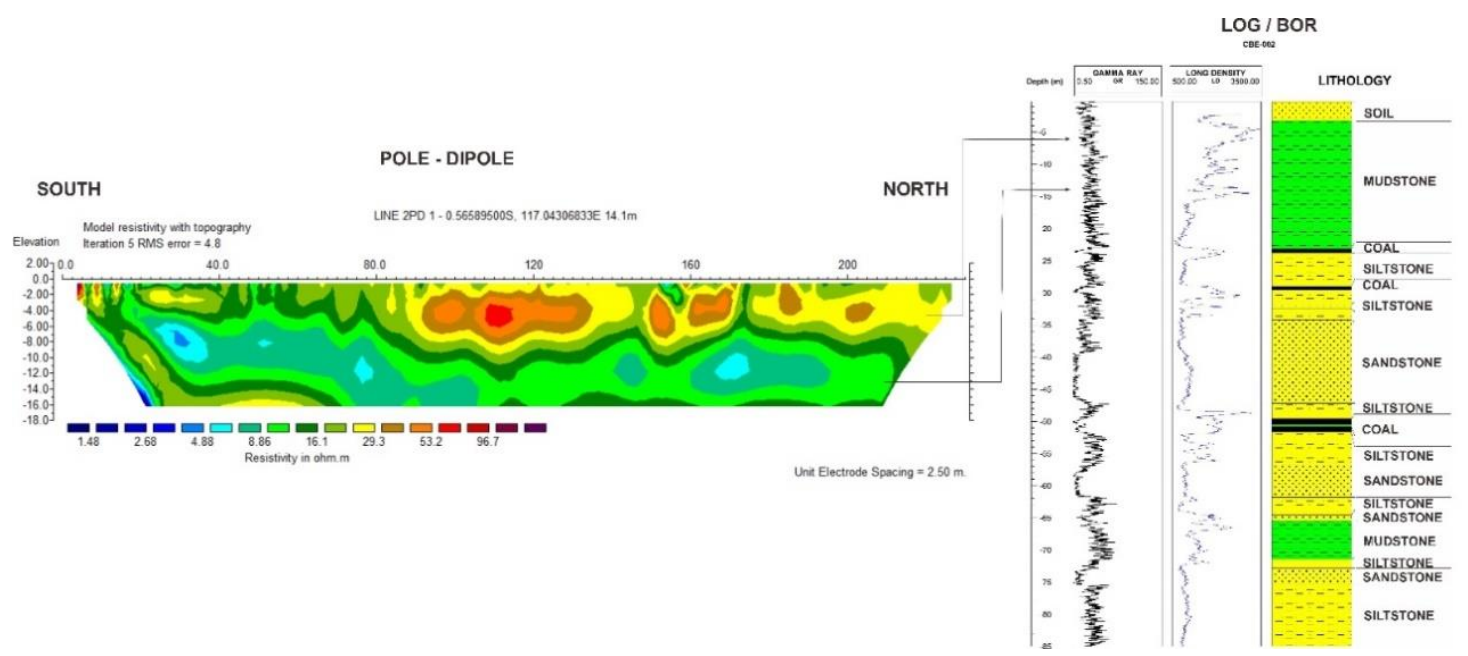

Figure 4. Resistivity profile of Pole-Dipole array 
Table 1. Borehole data and resistivity value of a different array

\begin{tabular}{lccc}
\hline Borehole Logging Data & Wenner-Schlumberger $(\Omega \mathrm{m})$ & Dipole-Dipole $(\Omega \mathrm{m})$ & Pole-Dipole $(\Omega \mathrm{m})$ \\
\hline Weathered Soil & $29.8-51.9$ & $14.8-78.6$ & $16.1-96.7$ \\
Mudstone & $5.6-17.1$ & $4.2-9.7$ & $1.4-8.8$ \\
Coal Seam & $24-34$ & $24-34$ & \\
Sandy Siltstone & $52-90$ & $34.1-78.6$ & \\
Sandstone & $90.2-275$ & 35 & 18 \\
\hline Total Depth $(\mathrm{m})$ & 45 & & \\
\hline
\end{tabular}

\section{CONCLUSION}

The interpretation of the WennerSchlumberger array has significant similarity with the lithology constrained by borehole data. It is recommended to use this array with any intention of using Electrical Resistivity Tomography in exploration and exploitation in this concession. The image of WennerSchlumberger clearly defines the stratigraphy of soil, siltstone, mudstone and coal that tilted to the north. The depth penetration of Wenner-Schlumberger array is deeper than that of Dipole-Dipole and Pole-Dipole arrays. This ERT method is recommended to apply in shallow depth, only up to $45 \mathrm{~m}$ depth.

\section{ACKNOWLEDGEMENTS}

The author would like to extend sincere attitude and appreciation to the RISTEKDIKTI for funding this research, the management of PT. Bukit Baiduri Energi for providing the Borehole data and access to the site of Marandai pit.

\section{REFERENCES}

Cloke, I. R., Moss, S. J. and Craig, J. (1999) "Structural controls on the evolution of the Kutai Basin, East Kalimantan," Journal of Asian Earth Sciences, 17(12), pp. 137-156. doi: 10.1016/S07439547(98)00036-1.

Daulay, B., Santoso, B. and Ningrum, N. S. (2015) "Evaluation of selected high rank coal in Kutai Basin, East Kalimantan relating to its coking properties," Indonesian Mining Journal, 18(1), pp. 110. doi: 10.30556/imj.Vol18.No1.2015.301.

Griffiths, D. H. and Barker, R. D. (1993) "Twodimensional resistivity imaging and modelling in areas of complex geology," Journal of Applied Geophysics, 29(3-4), pp. 211-226. doi: 10.1016/09269851(93)90005-J.

Grigorova, M., Tzankov, C., Kisyov, A., Koprev, I. and Dimovski, S. (2017) "Complex geophysical prospection - electrical resistivity tomography and geomagnetic survey for detecting limestone inclusions in mini Maritsa Iztok EAD," in Geobalcanica Proceedings 2017. Geobalcanica Society, pp. 31-38. doi: 10.18509/GBP.2017.05.

Hutchison, C. S. (1989) "Geological evolution of South-East Asia," in. Clarendon Press, p. 368.

Indonesia Coal Mining Association (2016) "Indonesia coal industry update," p. 24.

Land, D. H. and Jones, C. M. (1987) "Coal geology and exploration of part of the Tertiary Kutei Basin in East Kalimantan, Indonesia," Geological Society, London, Special Publications, 32(1), pp. 235-255. doi: 10.1144/GSL.SP.1987.032.01.14.

Loke, M. H. (2004) Tutorial: 2-D and 3-D electrical imaging surveys. www.geoelectrical.com. Available at: https://sites.ualberta.ca/ unsworth/UAclasses/223/loke_course_notes.pdf.

McClay, K., Dooley, T., Ferguson, A. and Poblet, J. (2000) "Tectonic evolution of the Sanga Sanga Block, Mahakam Delta, Kalimantan, Indonesia," AAPG Bulletin, 84(6), pp. 765-786. Available at: http://www.searchanddiscovery.com/pdf z/documents/Mcclay/images/00_0765.p df.html.

Ministry of Energy and Mineral Resources (2017) Handbook of energy \& economic statistics of Indonesia 2017. Jakarta: Ministry Of Energy and Mineral Resources Republic of Indonesia. Available at: https://www.esdm.go.id/assets/media/co ntent/content-handbook-of-energyeconomic-statistics-of-indonesia-2017.pdf. 
Application of Multi Array Electrical Resistivity Tomography in PT. Bukit Baiduri ... Supriyanto et al.

Moss, S. J., Carter, A., Baker, S. and Hurford, A. J. (1998) "A Late Oligocene tectonovolcanic event in East Kalimantan and the implications for tectonics and sedimentation in Borneo," Journal of the Geological Society, 155(1), pp. 177-192. doi: 10.1144/gsjgs.155.1.0177.
Moss, S. J. and Chambers, J. L. C. (2000) "Depositional modelling and facies architecture of rift and inversion episodes in the Kutai Basin, Kalimantan, Indonesia," in Proceedings of the Indonesian Petroleum Association 27th Annual Convention. Jakarta: Indonesian Petroleum Association, pp. 467-486. 
